\title{
Distractions towards the Use of Learning Management System (LMS): Evidence from Students during the Covid-19 Lockdown in a Developing Country Context
}

\author{
Daniel Opoku \\ School of Business, Department of Management Sciences, University of Education, Winneba
}

\begin{abstract}
The study is one of the first of its type to investigate the distractions towards the use of Learning Management System (LMS) during the Covid-19 shutdown and how it affected students' academic performance. The study sampled 456 learners who had returned to school following the Covid-19 lockout to resume their academic schedule. Data collected was evaluated using the SmartPLS tool for Structural Equation Modeling (SEM). Environmental distraction, technological distraction, and learning family distraction all had a detrimental impact on students' LMS usage, as found in the study. The use of the LMS was also found to have a detrimental impact on students' academic performance. The study's findings will assist lecturers, teachers or instructors in being courteous, as well as knowing the sort of evaluation to be utilized to assess students pursuing distance learning, as some of these distractions are likely to occur at home. As a result, the study contributes to the paucity of previous research on e-learning distractions in developing-country environments.
\end{abstract}

Keywords: E-learning, Distraction, Covid-19, Academic performance, Developing Country, SEM

DOI: $10.7176 / \mathrm{JEP} / 12-35-04$

Publication date: December $31^{\text {st }} 2021$

\section{Introduction}

Globally, the Covid 19 outbreak in December 2019 caused significant disruptions in numerous educational institutions. To halt the spread of the virus, Ghana's ministry of education issued an order shutting all public and private schools as an emergency precaution. The lockout prevented physical access to the classroom and pushed the regular academic schedule forward, affecting some students' graduation ceremony. However, as a result of the lockdown, numerous junior high schools, nursing schools, and teacher training institutes around the country are now adopting e-learning (Abbasi et al. 2020). Furthermore, schools that had been utilizing E-learning before the Covid-19 outbreak had fewer issues with it than schools that were adopting it for the first time. This was because students, teachers, and some facilitators did not undergo any thorough training before being subjected to it (Dampson 2021). Today, E-learning technologies are crucial in assisting schools to complete their studies amid the Covid 19 epidemic (Subedi et al. 2020). E-learning is therefore included in a wider field of technology-based education through the use of websites, learning portals, social network platforms (YouTube), video conferencing, and mobile apps. E-learning increases comprehension of the Internet for students, including university staff, professionals and businessmen. The effectiveness of an e-learning system depends on how students and teachers deliver the curriculum (Thongsri et al. 2019). Although it is reviewed in the literature that online learning is an excellent alternative to a physical classroom, students demonstrate a negative attitude towards engagement which might cause poor academic performance (Opoku et al. 2020; Rohman et al. 2020; Hasan \& Bao 2020). The usage of online learning tools such as the Learning Management System (LMS) is riddled with issues, according to the literature. There are worries in Africa that learners or students living in rural regions would struggle to satisfy the expectations of e-learning due to a lack of regular internet connectivity, which is critical to the successful operation of the LMS (Adebisi et al. 2020; Okereke et al. 2020). According to Danner \& Pessu (2013), the use of ICT applications in institutions is vulnerable to a lack of computers, internet access, and other associated concerns such as inadequate skills among students and tutors. On the contrary, due to a lack of interaction between students and lecturers or instructors, e-learning has the potential to lead to a loss of social and communication skills. Additional research has revealed that some flaws, such as a lack of online education infrastructure, greenness and inadequate knowledge and skills among teachers and students in using LMSs and the learning environment are also impeding successful integration of technologies into the classroom (Moore et al. 2018; Ndemo 2020). It is indicated that young urban people already in poor conditions and social exclusions continue to have a substantially uneven digital starting point (Bervell \& Umar 2017). Generally, several internet platforms at universities are commonly used for teaching and learning purposes. In a developed country like the USA, BbLearn, ANGEL Canvas, Moodle and Sakai are well-known teaching and learning platforms (Dobre 2015). Similarly, among the most popular LMS in Africa are "Blackboard, Sakai, KEWL, and Moodle" (Sharma, \& Vatta 2013).

At the University of Education, Winneba, the $\mathrm{VC}$ chancellor did his best by providing the needed infrastructure to support e-learning during the Covid-19 Lockdown. Although the school had a learning management system, its usage was not effective until the Covid-19 lockdown. This necessitated the need to call 
for online training for both teaching staff and administrative staff on effective use of the university LMS. Students were trained by their instructors using other social media applications to equip them on LMS usage. Learners were tasked to take quizzes, mid-semester examination as well as their final examinations online. Moodle is the name of the E-learning platform under research in this study. University instructors utilize Moodle to manage courses, assignments, class assessments, facilitate discussion forums and coordinate students' interim. Although the implementation and usage were successful, some distractions didn't enable some students to enjoy the successful usage of the Moodle. Students' academic performance using the LMS was seen to have declined as compared to the normal face to face traditional learning. The motivation behind this study is as a result of students' poor academic performance during the covid-19 lockdown using the Moodle LMS. A brief discussion with some students revealed that environmental noise, learning family issues, domestic problems and phone notifications (apps, network operators, incoming calls etc.) were some of the challenges they faced during the Covid-19 lockdown when using the LMS. The study, therefore decide to explore these concerns by students on a large scale of students to find out if indeed these distractions affected their LMS usage during the lockdown. The outcomes of this study will add to the body of knowledge and literature by presenting empirical facts that explain the characteristics that inhibit university students' successful adoption and usage of Moodle LMS at home.

\section{Factors that influence E-learning Distraction 2.1 Technology Notification}

Technological devices play a vital role in E-learning adoption. Many students access their online materials using either their laptops, iPads, mobile phones etc. In the Ghanaian economy, students have been observed to utilize their mobile phones more than any other device to access online content. They use their mobile phones to take quizzes, exams, and download homework. Students who use mobile phones receive notifications when new messages, emails, social media updates, and other events are posted. Many students use their mobile phones as a Hotspot to share the internet on their laptops or tablets. It is realized that notification from apps, SMS by the network operator as well as incoming calls has become a destructive motion that affects students' online quiz (e.g. Answering Multiple Choice Questions (MCQ) online). While the impact of notification at the workplace environment has been extensively researched (Kanjo et al. 2017; Ho \& Intille 2005; Iqbal \& Horvitz 2010; Leiva et al. 2012; Hernández-Reyes et al. 2020), nature of smartphone notification and their impact on students using Elearning are little understood. Pielot et al. (2014) emphasized the detrimental consequences of notifications on job efficiency. The authors reported dealing with an average of 63.5 alerts each day, with the majority coming from messengers and email. However, frequent notification is likely to affect job performance (Hernández-Reyes et al. 2020). Furthermore, Leiva et al. (2012) believe that phone calls interrupting app usage dramatically increase the time a user spends finishing a particular task. Ho \& Intille (2005) studied how notifications may be given during the transition from one physical activity to another. Their findings show that when alerts are presented between two physical activities, such as either sitting or walking, they are regarded more favourably. However, it is clear that people often find it difficult to resume prior work after being stopped by phone calls, texts, or notifications, or a conversation with anyone (Czerwinski et al. 2004). To summarize, the majority of previous research has been on desktop and office environments. While previous research has looked at notifications in the setting of mobile devices, it appears that none of these studies has looked at how notifications affect students' e-learning utilization via their cell phones. What is lacking in the literature is how notifications on the phones distract students when taking their exams online, specifically answering test questions. Therefore, the study hypothesized that:

H1: Technology notification had a negative effect on students Moodle usage during Covid-19 Lockdown

\subsection{Learning-Family Distraction}

The COVID-19 epidemic has created an exceptional scenario in which many individuals have been forced to learn from home (Oakman et al. 2020). Students who learn from home typically tend to learn fewer hours due to more family distractions than being in school. The study characterized the learning-family distraction as domestic duties, errands and other activities at home that impede and interfere with students' attention to study at home. In some African countries like Ghana, Togo, Nigeria etc., household duties are often undertaken by females in the family, whereas outside tasks are performed by males in the family (Kissi et al. 2018; Annor 2015). While these activities may appear to be normal in the family's daily routines, they are unplanned (Kissi et al. 2018) and so take up time that could be used for school activities. Furthermore, too many domestic actives have been considered as one of the hurdle that affect students in performing classroom activities as cited by Mordkowitz \& Ginsburg (1987). The majority of families in our culture do not appear to prioritize their children's education. Some parents appear to have erroneous beliefs about their children's academic success. More often they feel reluctant to fulfil their duties and encouraged in their children's academic achievement. Some individuals believe that widespread failure or success in schools may be attributed to teachers and school administrators. During the covid-19 lockdown, a preliminary investigation declared that many students were not happy taking online tests or quizzes at home due to learning family conflict (e.g. too much domestic activities, too many errands, siblings playing and making loud 
noise etc.) caused by their family members. However, in most African communities, it is quite unusual to see an individual occupying his or her room in the family house. More often, you occupy a room with your siblings or with any other relatives. This level of occupancy sometimes distracts student learners when there is a nuisance. Sometimes children are being called by their parents to perform a task or send them for some errands, even though the parents are aware that their children are studying. Although learning from home allow you to "have more time with family and less commuting time, it also has several known demerits (Hoffman et al. 2020; Bergefurt et al. 2021). Some students saw this as a major challenge faced during the lockdown, which they believe affected their academic performance. Although earlier research has shown that distractions in the employee workplace can have a detrimental impact on employees' well-being (Bergefurt et al. 2021), little is known about distractions while learning at home and how it influences academic performance, since there is paucity of literature exploring how family distractions affect children learning at home. Hence, the following hypothesis was derived. H2: learning Family-Distraction had a negative effect on students Moodle usage during Covid-19 Lockdown

\subsection{Environmental Distraction}

The home environment is more crucial than anything else for students' academic performance (Younas et al. 2021; Bergefurt et al. 2021; Crawford \& Zygouris-Coe 2006). However, encouragement from the environment may stimulate learning and improve a student's capabilities, whilst discouragement from the environment just depresses a student's talent. One of the most critical elements influencing student performance and academic accomplishment is the home environment. When students experience good and serene environments without distraction it encourages and motivates them to study much better. Moreover, some environmental noise can divert learners focus away from the focal task (Hughes 2014). Environmental distractions in this context are defined as the noise around and outside the learner's environment that distracts him or her when learning. This could be music played by neighbours, aircraft noise, road traffic noise, traders who move around the environment advertising their product verbally etc. Obeta (2014) emphasized that the location of the home of the learners have an impact on their academic performance. Wong et al. (2002) investigated the various noise sources that affect people in the community. It was realized in the authors' study that among the various environmental noise, the most annoying one was traffic noises, which is followed by construction, aircraft, neighbouring and industrial noise. This kind of noise sometimes affects students, when they are writing online quiz specifically multiple-choice questions (MCQ). Although there are studies that have explored some environmental distractions in schools and offices (Lundquist et al. 2000; Lee \& Brand 2010; Woolner \& Hall 2010), the environmental distraction towards e-learning has been seen to receive little concern. It is of interest to find out how this distraction affected students' e-learning adoption during the Covid-19 lockdown.

H3: Environmental Distraction had a negative effect on students Moodle usage during Covid-19 Lockdown

\subsection{LMS Application Usage}

Actual system usage is a measurement of an individual's behaviours or actions when utilizing a certain technology, such as online learning (Hassanzadeh et al. 2012). In accordance with Davis, Bagozzi, \& Warshaw (1989), an "individual's behavioural intention leads to actual behaviour or system utilization". Mohammadi (2015) corroborated this in his research study on e-Learning systems. Suki (2011) have also corroborated this in various research. The Technology Adoption Model employs actual usage to reflect a self-report measure of time or frequency of adopting the system, whereas behavioural intention to use measures the chance that a person will adopt the system (Davis et al., 1989). Several studies have demonstrated that there is theoretical and empirical support for individual system usage (Opoku, Pobee \& Okyerih 2020; Chong et al. 2012; Suki 2011; Vijayasarathy 2004). Actual system usage is a measurement of an individual's behaviours or actions when utilizing certain technology. Davis et al. (1989), emphasize that an individual's behavioural intention leads to real behaviour or actual system usage. Thus, an individual behavioural intention will lead to their actual behaviour. This has been confirmed in the studies of Mohammadi (2015), Chong et al. (2012) and Suki (2011). It is therefore hypothesized that;

H4: Moodle usage had a negative effect on student performance during Covid-19 Lockdown

\subsection{Student Academic Performance}

Students' academic performance is a vital key to improving student learning. It is influenced by socioeconomic, personal factor and environmental factors. However, recognizing these variables and their influence on student performance might aid in their management (Shahibi et al. 2017; Baradwaj \& Pal 2012). When students can perform very well, they obtain much desire in studying hard. However, the performance of students towards academic work may not only be affected by their hard work but also parent involvement (Kweon et al. 2017). Some studies have also indicated that the learning environment sometimes can contribute to low students' academic performance if such an environment is not conducive for students (e.g. Topor 2010; Kweon et al. 2017). Other studies have also indicated that student academic performance is influenced by both internal and external factors 
(Mushtaq \& Khan 2012). Internal factors constitute learning facilities, class environment, technology usage, instructors' role in the class and the kind of examination systems that exist whereas the external factors include family problems, financial, social and accommodation problems (Mushtaq \& Khan 2012; Kweon et al. 2017; Baradwaj \& Pal 2012). Although there are some studies on students' academic performance, it seems none of these studies has investigated covid-19 lockdown distractions on student performance. For example, in a study by Harb and El-Shaarawi (2006), the authors found English competence as an important factor that affects students' academic performance. In a study by Shahibi \& Rusli (2017), the authors found that using internet media for instruction improves students' academic achievement. According to Adeoye et al. (2020), e-learning comes with some drawbacks with sometimes demote it implementation. To the best of my knowledge, there have been scanty reports presenting how e-learning has been adopted during the Covid-19 epidemic. This gives room for more academic research.

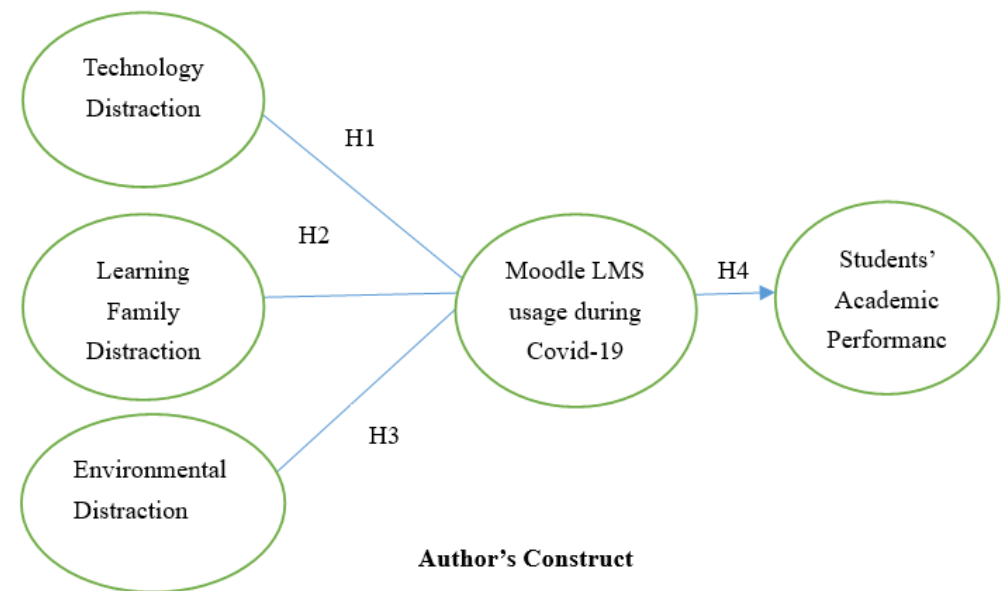

Figure 1.1: Study Framework

\section{Study Method and Material}

The study examined the distractions that students encountered during the covid-19 lock and how they influenced their academic performance. The Moodle is one of the most used E-learning applications by many institutions. The system allows lecturers or instructors to mount their courses, upload course materials, and conduct quizzes and exams as well. Students use this system to participate in group discussions, submit homework, and connect with their instructors or lecturers. To achieve the study's goal, a cross-sectional survey methodology was adopted. After students returned to school following the covid-19 lockdown, a sample of 480 questionnaires were distributed. However, 456 questionnaires were retrieved and used for the study analysis. Likert scale questions were used to illustrate how much participants agreed or disagreed with the statements used to test the variables. Items measuring the technology distraction and environmental distractions were developed based on students' experience and concerns. These items were modified by two scholars who have in-depth knowledge and has been practicing e-learning. Items measuring learning family distraction were adapted from Kissi et al. (2018) and modified. The gathered data was evaluated using the SmartPLS tool for Structural Equation Modeling (SEM). The SEM is a versatile and successful analytical tool for identifying structures and their interactions based on observational data. The study presented data on descriptive statistics of the demographic variable, evaluated both the measurement model (i.e. reliability, validity, normality and collinearity test) and the structural model (i.e. coefficient of determination, model predictive relevance, hypothesis). The items used were written to fit the setting of the study.

\section{Results Presentation}

The demographic information of the subjects was initially reported in the research. The study also tested the model's applicability by checking the data's normality, reliability and validity. Furthermore, the structural model was evaluated to assess the model's predictive ability, accuracy, and correlations among the components. The study consists of 456 university students as already presented in the methodology. According to Table 1, more than half of those who participated in this study $(61.8 \%)$ were males, while the rest $(38.2 \%)$ were females. Students aged 18 to 24 were found to be the most common responses $(91.2 \%)$. In terms of academic Year, 38.4\% were determined to be at the first year, $22.6 \%$ at second year, $20.0 \%$ at the third year, and $19.1 \%$ at fourth year. 
Table 1: Background Information

\begin{tabular}{llll}
\hline Socio-demographic & Response & Frequency & Percentage
\end{tabular}

\begin{tabular}{llcc}
\hline Gender & Male & 282 & \\
& Female & 174 & 61.8 \\
\hline Age & & 38.2 \\
& $18-24$ years & 416 & 91.2 \\
& $25-31$ years & 34 & 7.5 \\
& Above 31 years & 6 & 1.3 \\
\hline Academic Level & & & \\
& 100 & 175 & 38.4 \\
& 200 & 103 & 22.6 \\
& 300 & 91 & 20.0 \\
& 400 & 87 & 19.1 \\
\hline
\end{tabular}

\section{Normality Test and Collinearity}

A normality test was run to see if the data warranted further investigation. The skewness-Kurtosis approach was used to determine the data set's normality (Byrne 2013). The findings were discovered to be on the predicted scales. As shown in Table 2, all skewness values between 2 and +2 and kurtosis values between -7 and +7 validated the data's normality (Byrne 2013). However, when data are collected from multiple sources, there can be a strong correlation between items or indicators, which can lead to the issue of multicollinearity. To prevent this, values for Variance Inflation Factor (VIF) should be less than 5 (VIF < 5) (Kim 2019). From the analysis, it was seen that all values of VIF were less than 5, which indicate no issue of multicollinearity. Table 2 presents the findings.

Table 2: Loadings and Normality of Measurement

\begin{tabular}{|c|c|c|c|c|c|c|c|}
\hline & \multirow[b]{2}{*}{ Items } & \multirow{2}{*}{$\begin{array}{c}\text { Factor } \\
\text { Loadings }(\lambda)\end{array}$} & \multirow{2}{*}{ VIF } & \multicolumn{2}{|c|}{ Skewness } & \multicolumn{2}{|c|}{ Kurtosis } \\
\hline & & & & Value & $\begin{array}{l}\text { Std. } \\
\text { Error }\end{array}$ & Value & $\begin{array}{l}\text { Std. } \\
\text { Error }\end{array}$ \\
\hline LFD1 & $\begin{array}{l}\text { Too many domestic activities distracted me at } \\
\text { home when using Moodle during the Covid-19 } \\
\text { lockdown }\end{array}$ & 0.882 & 1.894 & -.877 & .162 & .305 & .322 \\
\hline LFD2 & $\begin{array}{l}\text { Loud music played at home by my parents } \\
\text { distracted me when learning using the Moodle }\end{array}$ & 0.854 & 1.793 & -.999 & .162 & .215 & .322 \\
\hline LFD3 & $\begin{array}{l}\text { My parents usually send me for errands which } \\
\text { affected my Moodle usage }\end{array}$ & 0.798 & 1.567 & -.756 & .162 & -.107 & .322 \\
\hline TED1 & $\begin{array}{l}\text { Poor network connectivity distracted me when } \\
\text { using Moodle LMS during Covid-19 } \\
\text { Lockdown }\end{array}$ & 0.6 & 1.429 & -.694 & .162 & .219 & .322 \\
\hline TED2 & $\begin{array}{l}\text { Incoming calls distracted me when using my } \\
\text { phone to access Moodle LMS during the } \\
\text { Covid-19 Lockdown }\end{array}$ & 0.760 & 1.647 & -.823 & .162 & .116 & .322 \\
\hline TED3 & $\begin{array}{l}\text { Frequent software updates that come to my } \\
\text { phone were distracting me when using Moodle } \\
\text { LMS during Covid-19 Lockdown }\end{array}$ & 0.919 & 1.351 & -.755 & .162 & .046 & .322 \\
\hline EVD1 & $\begin{array}{l}\text { Vehicle noise at where I stay was distracting } \\
\text { me when using Moodle LMS during the Covid- } \\
19 \text { Lockdown }\end{array}$ & 0.802 & 1.652 & -.829 & .162 & .117 & .322 \\
\hline EVD2 & $\begin{array}{l}\text { Noise from shops within my environment were } \\
\text { distracting me to pay attention to my Moodle } \\
\text { LMS usage during the Covid-19 Lockdown. }\end{array}$ & 0.887 & 2.126 & 1.043 & .162 & .363 & .322 \\
\hline EVD3 & $\begin{array}{l}\text { Music Played by my neighbours was } \\
\text { distracting me when using Moodle LMS during } \\
\text { the Covid-19 Lockdown }\end{array}$ & 0.884 & 1.953 & -.995 & .162 & .521 & .322 \\
\hline ACP1 & $\begin{array}{l}\text { Moodle helped me to learn more quickly during } \\
\text { the Covid-19 lockdown }\end{array}$ & 0.873 & 2.304 & -.438 & .162 & -.598 & .322 \\
\hline ACP2 & $\begin{array}{l}\text { Moodle LMS helped me to complete my } \\
\text { assignments quickly during the Covid-19 } \\
\text { lockdown }\end{array}$ & 0.856 & 2.175 & -.790 & .162 & -.028 & .322 \\
\hline
\end{tabular}




\begin{tabular}{|c|c|c|c|c|c|c|c|}
\hline & \multirow[b]{2}{*}{ Items } & \multirow{2}{*}{$\begin{array}{c}\text { Factor } \\
\text { Loadings }(\lambda)\end{array}$} & \multirow{2}{*}{ VIF } & \multicolumn{2}{|c|}{ Skewness } & \multicolumn{2}{|c|}{ Kurtosis } \\
\hline & & & & Value & $\begin{array}{c}\text { Std. } \\
\text { Error }\end{array}$ & Value & $\begin{array}{l}\text { Std. } \\
\text { Error }\end{array}$ \\
\hline ACP3 & $\begin{array}{l}\text { Moodle LMS helped me acquire new } \\
\text { knowledge }\end{array}$ & 0.797 & 1.797 & -.722 & .162 & -.173 & .322 \\
\hline ACP4 & $\begin{array}{l}\text { Moodle LMS helped me improve my overall } \\
\text { academic performance }\end{array}$ & 0.857 & 2.166 & -.875 & .162 & -.038 & .322 \\
\hline MOU1 & $\begin{array}{l}\text { I used the University Moodle to communicate } \\
\text { and share knowledge with my colleagues during } \\
\text { the Covid-19 lockdown }\end{array}$ & 0.840 & 1.919 & -.187 & .162 & $1.294^{-}$ & .322 \\
\hline MOU2 & $\begin{array}{l}\text { I used the University Moodle to accomplish and } \\
\text { submit my assignments during the Covid }-19 \\
\text { Lockdown }\end{array}$ & 0.911 & 2.719 & -.131 & .162 & $1.115^{-}$ & .322 \\
\hline MOU3 & $\begin{array}{l}\text { I used the University Moodle to access learning } \\
\text { resources during the Covid-19 lockdown }\end{array}$ & 0.909 & 2.457 & -.386 & .162 & -.700 & .322 \\
\hline
\end{tabular}

\subsection{Measurement Model Evaluation}

The study evaluated the measurement model using Confirmatory Factor Analysis. All reliability and validity values were calculated. Factor loadings larger than 0.6 were considered (Gefen \& Straub 2005). Cronbach's alpha was used to calculate the internal consistency of the constructs, with suggested values greater than 0.5. ( Hu \& Bentler 1998; Hasan \& Boa 2020; Hair et al. 2010). The composite reliability of the constructs was also found to be more than the required level of 0.70 , demonstrating exceptional construct dependability (Fornell \& Larcker 1981). Convergent validity was also calculated using AVE, which implies that each item measures what it was designed to measure. The Average Variation Extracted (AVE) criterion was more than 0.50, indicating that the measurement error was smaller than the structural observed variance. Convergent validity was good, as indicated in table 3, because all AVE values were more than 0.5 according to Henseler et al. (2015). The Path Analysis Diagram is also shown in Figure 1.

Figure 1: Path Analysis Diagram

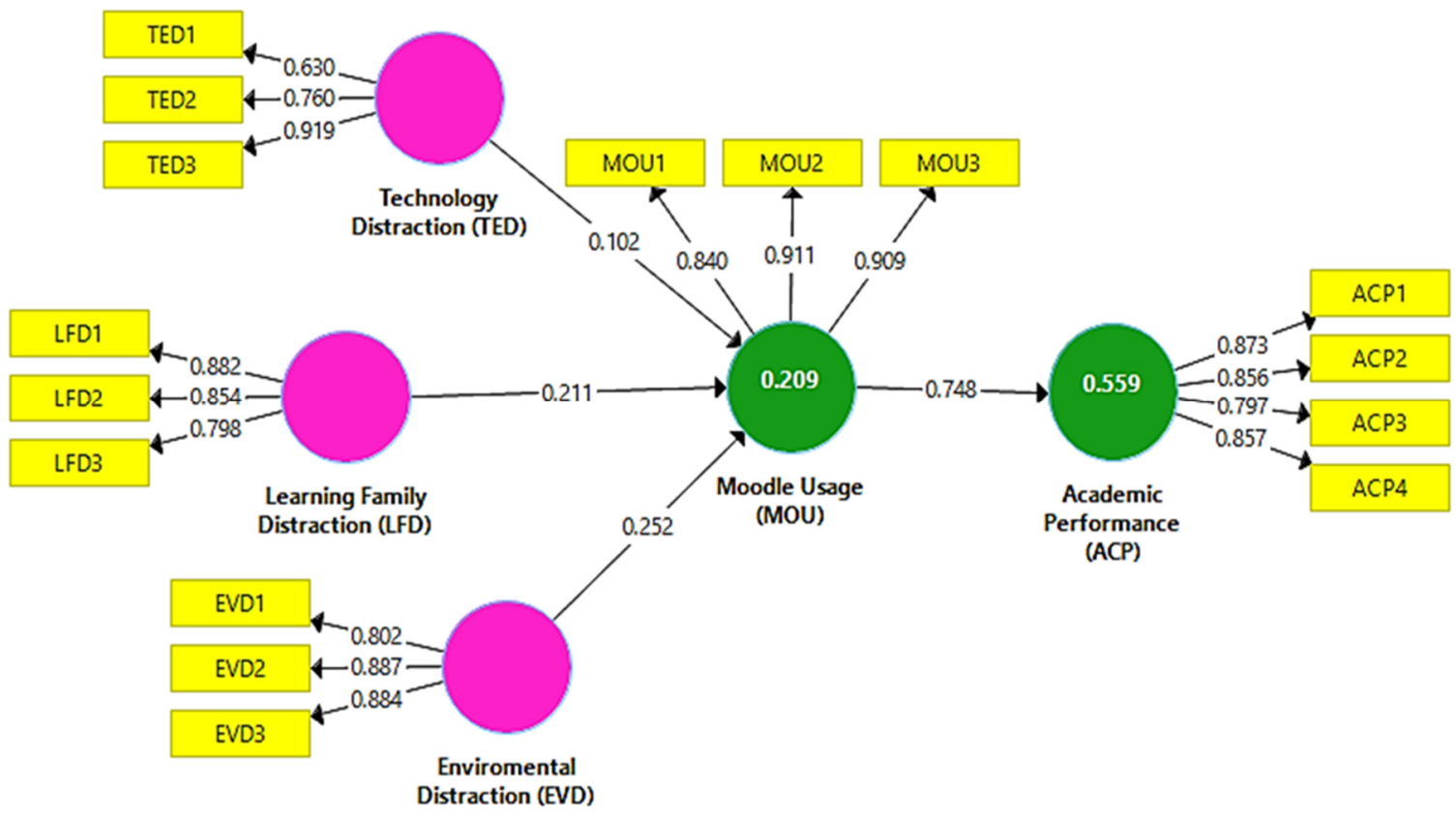


Table 3: Convergent, Composite and Internal Consistency Analysis

\begin{tabular}{lccc}
\hline Constructs & $\begin{array}{c}\text { Cronbach's } \\
\text { Alpha (o) }\end{array}$ & $\begin{array}{c}\text { Composite } \\
\text { Reliability }\end{array}$ & $\begin{array}{c}\text { Average Variance } \\
\text { Extracted (AVE) }\end{array}$ \\
\hline Technology Distraction (TED) & 0.723 & 0.819 & 0.606 \\
Learning Family Distraction (LFD) & 0.801 & 0.882 & 0.715 \\
Environmental Distraction (EVD) & 0.822 & 0.893 & 0.737 \\
Moodle Usage (MOU) & 0.865 & 0.917 & 0.787 \\
Academic Performance (ACP) & 0.868 & 0.910 & 0.716 \\
\hline A
\end{tabular}

AVE: Average Variance Extracted $=\sum \lambda^{2} / n=\mathrm{A}>0.500$

$\mathrm{CR}>0.700, \alpha>0.700$

\subsection{Discriminant validity}

Discriminant validity, which describes how one concept differs (is distinct) from the others, was also assessed. Fornell-Larcker measure was used to evaluate discriminant validity (Henseler et al. 2015). Discriminant validity is deemed to be reached if the square root of AVE is larger than the inner correlation of the factors. Table 4 shows acceptance of discriminant validity among components. The Heterotrait-Monotrait ratio (HTMT) criteria is another way to support discriminant validity. All correlation values must be less than 0.900 for HTMT to be accomplished (Henseler et al. 2016). Table 5 demonstrated that the discriminant validity was excellent.

Table 4: Fornell-Larcker Criterion (Discriminant Validity)

\begin{tabular}{lccccc}
\hline & ACP & EVD & LFD & MOU & TED \\
\hline ACP & $\mathbf{0 . 8 4 6}$ & & & & \\
EVD & 0.437 & $\mathbf{0 . 8 5 8}$ & & & \\
LFD & 0.434 & 0.410 & $\mathbf{0 . 8 4 5}$ & & \\
MOU & 0.748 & 0.384 & 0.370 & $\mathbf{0 . 8 8 7}$ & \\
TED & 0.389 & 0.452 & 0.550 & 0.332 & $\mathbf{0 . 7 7 9}$ \\
\hline
\end{tabular}

Table 5: Heterotrait-Monotrait Ratio (HTMT)

\begin{tabular}{llllll}
\hline & ACP & EVD & LFD & MOU & TED \\
\hline ACP & & & & & \\
EVD & 0.512 & & & \\
LFD & 0.516 & 0.505 & & \\
MOU & 0.854 & 0.449 & 0.432 & \\
TED & 0.434 & 0.588 & 0.705 & 0.340 & \\
\hline
\end{tabular}

\section{Structural Model Evaluation}

The coefficient of determination $\left(\mathrm{R}^{2}\right)$ is commonly used to assess the prediction capacity of a structural model. It illustrates how the independent variable predicts the variation in the dependent variable. The coefficient of determination was examined at two different levels (Table 6). The first explains the variation in Moodle usage $\left(\mathrm{R}^{2}\right.$ $\mathrm{MOU})$, while the second explains the variation in Student Academic Performance $\left(\mathrm{R}_{\mathrm{ACP}}^{2}\right) . \mathrm{R}_{\mathrm{MOU}}^{2}=0.209$ implies that technological distraction, environmental distraction, and learning family distraction account for $20.9 \%$ of the variation in student Moodle usage. $\mathrm{R}^{2} \mathrm{ACP}=0.559$ implies that Moodle usage explains $55.9 \%$ of the variation in student academic achievement. The Stone-Geisser Indicator $\left(\mathrm{Q}^{2}\right)$ was also used to measure the model's predictive significance (Henseler et al. 2015). An indicator value larger than zero indicates a high prediction quality (Henseler et al. 2015). The values of $\mathrm{Q}^{2}$ in Table 6 suggest that the model is accurate and that the constructs are crucial for general model tuning.

Table 6: Model Power and Relevance

\begin{tabular}{lcc}
\hline Construct & $\left.\mathbf{( R}^{\mathbf{2}}\right)$ & $\left.\mathbf{( Q}^{\mathbf{2}}\right)$ \\
\hline Moodle Usage (MOU) & 0.209 & 0.226 \\
Academic Performance (ACP) & 0.587 & 0.392 \\
\hline
\end{tabular}

To evaluate the significance level of the latent variables, the construct relationship was established using the Bootstrapping procedure in Partial Least Square. Each of the four hypotheses was examined (H1 to H4, see Table 7). During the Covid-19 Lockdown, technology distraction had a substantial influence on students' Moodle usage $(\beta=-0.182$, t-value $=2.231, \mathrm{P}<0.039)$. As a result, $\mathrm{H} 1$ is supported. Learning family distraction had a substantial detrimental influence on students' Moodle usage during the Covid-19 Lockdown $(\beta=-0.210$, t-value $=2.552, P$ $<0.011)$. As a result, H2 is supported. Environmental distraction had a negative significant effect on students 
Moodle usage during Covid-19 lockdown $(\beta=-0.252$, t-value $=3.442, \mathrm{P}<0.001)$. Hence, $\mathrm{H} 3$ is supported. Finally, Moodle usage by students showed a negative influence on academic performance $(\beta=-0.447$, t-value $=6.063, P$ $<0.000)$. Hence, $\mathrm{H} 4$ is supported.

Table 7: Path Coefficient and P-values

\begin{tabular}{lcccll}
\hline $\begin{array}{l}\text { Structural } \\
\text { Relationship }\end{array}$ & Hypotheses & Standardized Beta (B) & $\begin{array}{c}\text { T-Statistics } \\
(t \text {-Value }>1.99)\end{array}$ & P Values & $\begin{array}{l}\text { Status of The } \\
\text { Hypothesis }\end{array}$ \\
\hline TED $\rightarrow$ MOU & H1 & -0.182 & 2.231 & $0.039^{* *}$ & Supported \\
LFD $\rightarrow$ MOU & H2 & -0.210 & 2.552 & $0.011^{* *}$ & Supported \\
EVD $\rightarrow$ MOU & H3 & -0.252 & 3.442 & $0.001^{* *}$ & Supported \\
MOU $\rightarrow$ ACP & H4 & -0.447 & 6.063 & $0.000^{* *}$ & Supported \\
\hline
\end{tabular}

Sig. ${ }^{*} p<0.10 ;{ }^{* *} p<0.05 ;{ }^{* * *} p<0.01, t-$ Value $>1.99$,

\section{Discussion and Implications}

After taking some quizzes and examinations using Moodle LMS during the covid-19 lockout, students' academic performance was shown to have deteriorated. Although numerous academic studies in both developed and developing countries have praised e-learning, it appears that adoption rates vary by nation. However, there are still some drawbacks in developing countries like Ghana. This study used a quantitative way to investigate the relationships between destructive factors and how they influenced student Moodle usage and academic performance during the Covid-19 lockdown in Ghana. The findings confirmed Hypothesis 1, indicating that technological distraction had a detrimental impact on students' Moodle usage. According to the survey, the majority of students who used their mobile phones to access their learning materials experienced phone call interruption, mobile app update alerts, and network operator messages. This finding supports earlier research that found notification had a detrimental impact on work efficiency (Kanjo et al. 2017; Hernández-Reyes et al. 2020). The study also verified the second hypothesis $(\mathrm{H} 2)$, which stated that learning family distraction has a negative effect on students' use of Moodle LMS. It is often understood that the majority of families in several African societies do not appear to prioritize their children's education. Some parents appear to have incorrect assumptions about their children's academic achievement. More often than not, they are hesitant to carry out their responsibilities while being proud of their children's academic performance. Some students have been seen to engage in a variety of household tasks that consume a significant portion of their studying time at home. This data lends credence to Kissi et al. (2018) work on learning family conflict. The hypothesis (H3) of environmental distraction had a negative significant influence on students' Moodle usage. It was discovered that some of the students were living in an unsuitable environment for studying. They have no choice but to manage in such a setting. Encouragement from the environment, on the other hand, may accelerate learning and develop a student's skills, but discouragement from the environment just depresses a student's potential. Loud noise from neighbouring residences, traffic noise, and noise from vendors advertising their products while wandering in the area have all been seen to have an impact on students studying at home. These findings back with prior research indicating that the environment is more important than everything else for students' academic performance (Younas et al. 2021; Bergefurt et al. 2021). Finally, the findings validated hypothesis 4, which stated that students' use of Moodle had a negative effect on academic performance. External variables (e.g., environmental, learning family distractions, etc.) that inhibit continuous use of the Moodle LMS might explain the detrimental effect of system utilization on academic performance. This type of discouragement might undoubtedly have a negative effect on performance. Furthermore, there are worries that learners or students living in rural regions may struggle to fulfil the expectations of e-learning due to a lack of consistent internet connectivity, which plays a critical role in maintaining the proper operation of the LMS and may impair academic achievement.

\section{Implication, Limitation and Future Study}

This study is one of the first kind to investigate destructive factors that hinder the use of the LMS during the Covid -19 lockdown. Although there is quite some study on e-learning, this study explores the factors that interfere with students' e-learning at home. The study proposed three destructive variables and validated one variable in the technology acceptance model. The study proposed model was seen to clarify $55.9 \%$ of the variability on students' academic performance relating to E-learning on Covid-19 lockdown. The study findings would also help teachers or instructors to be considerate and also know the type of assessment to be used to assess students offering distance learning since there are likely to encounter some of these distractions at home. The study provided a significant outcome but it is not without limitation. The sample size was composed purposively to a specific target population. However, the findings might not be generalized to other developed and developing country contexts. Further studies can inculcate other factors to moderate or mediate the proposed model. 


\section{Conclusion}

Today, E-learning solutions are crucial in assisting schools to complete their studies throughout the Covid-19 epidemic. Schools that previously did not provide online education have all recognized the benefits of online education and have enrolled in it. During the Covid-19 pandemic, several researchers took use of the opportunity to conduct more studies on E-learning adoption. This study looked at the distractions that hampered students' elearning during the Covid-19 lockout. The empirical investigation revealed students' low academic performance during the covid-19 lockout as a result of environmental, technological, and learning family distractions that influenced their use of the Moodle LMS. These characteristics should be taken into account when evaluating students' LMS usage because it has a detrimental impact on their academic performance.

\section{References}

Adebisi, Y. A., Agboola, P., \& Okereke, M. (2020), "COVID-19 pandemic: medical and pharmacy education in Nigeria”, International Journal of Medical Students, 8(2), 162-164.

Adeoye, I. A., Adanikin, A. F. \& Adanikin, A. (2020), "COVID-19 and e-learning: Nigeria tertiary education system experience", International Journal of Research and Innovation in Applied Science, 5(5), 28-31.

Annor, F. (2015), "Work-family conflict: A synthesis of the research from cross-national perspective", Journal of Social Sciences, 12(1), 1-13.

Baradwaj B., K, \& Pal S. (2012) Mining educational data to analyze students' performance. IJACSA, 2, 63-69.

Bervell, B. \& Umar, I. U (2017), "A decade of LMS acceptance and adoption research in Sub-Sahara African higher education: A systematic review of models, methodologies, milestones and main challenges", Eurasia Journal of Mathematics, Science and Technology Education, no. 13(11), 2017, pp. 7269-7286.

Czerwinski, M., Horvitz, E., \& Wilhite, S. A. (2004), "Diary study of task switching and interruptions", In Proc. CHI '04, ACM.

Dampson, D. G. (2021), "Determinants of Learning Management System Adoption in an Era of COVID-19: Evidence from a Ghanaian University", European Journal of Education and Pedagogy, 2(3), 80-87.

Danner, R. B., \& Pessu, C. O. (2013), "A survey of ICT competencies among students in teacher preparation programmes at the University of Benin, Benin City, Nigeria", Journal of Information Technology Education: Research, 12(1), 33-49.

Davis, F. (1989), "Perceived Usefulness Perceived Ease of Use and User Acceptance of Information Technology", MIS Quaterly, vol. 13, pp. 319-340, 1989.

Dobre, I. (2015), "Learning management systems for higher education-an overview of available options for Higher Education Organizations", Procedia-social and behavioral sciences, 180, pp. 313-320

Fornell, C., \& Larcker, D. F. (1981), "Structural Equation Models with Unobservable Variables and Measurement Error: Algebra and Statistics. Journal of Marketing Research", 18(3), 382-388. https://doi.org/10.2307/3150980

Gefen, D., \& Straub, D. (2005), "A practical guide to factorial validity using PLS-Graph: Tutorial and annotated example", Communications of the Association for Information systems, 16(1), 5.

Gonzalez, T., De La Rubia, M. A., Hincz, K. P., Comas-Lopez, M., Subirats, L., Fort, S., \& Sacha, G. M. (2020), "Influence of COVID-19 confinement on students' performance in higher education", PloS one, 15(10), e0239490.

Hair, J. F., Black, W. C., Babin, B. J., \& Anderson, R. E. (2010),”Multivariate data analysis: International version”, New Jersey, Pearson.

Hair, J. F., Ringle, C. M., \& Sarstedt, M. (2012), "Partial least squares: the better approach to structural equation modelling", Long Range Planning, 45(5-6), 312-319.

Hasan, N., \& Bao, Y. (2020), "Impact of "e-Learning crack-up" perception on psychological distress among college students during COVID-19 pandemic: A mediating role of fear of academic year loss". Children and Youth Services Review, 118, 105355.

Henseler, J., Hubona, G. and Ray, P.A. (2016), "Using PLS path modeling in new technology research: updated guidelines", Industrial Management \& Data Systems, Vol. 116 No. 1, pp. 2-20.

Hernández-Reyes, A., Cámara-Martos, F., Recio, G. M., Molina-Luque, R., Romero-Saldaña, M., \& Rojas, R. M. (2020), "Push notifications from a mobile app to improve the body composition of overweight or obese women: randomized controlled trial". JMIR mHealth and uHealth, 8(2), e13747.

Ho, J., \& Intille, S. S. (2005), "Using context-aware computing to reduce the perceived burden of interruptions from mobile devices”, In Proc. CHI '05, ACM

Hoffman, K. E., Garner, D. Koong A. C, \& W. A. (2020), "Woodward, "Understanding the Intersection of Working from Home and Burnout to Optimize Post-COVID19 Work Arrangements in Radiation Oncology," Int. J. Radiat. Oncol. Biol. Phys., 2(108), 370-373

Hu, L. T., \& Bentler, P. M. (1998), "Fit indices in covariance structure modeling: Sensitivity to underparameterized model misspecification", Psychological methods, 3(4), 424. 
Iqbal, S. T., \& Horvitz, E. (2010), "Notifications and awareness: a field study of alert usage and preferences", In Proc. CSCW'10, ACM

Kanjo, E., Kuss, D. J., \& Ang, C. S. (2017), "NotiMind: utilizing responses to smart phone notifications as affective sensors", IEEE Access, 5, 22023-22035.

Kim, J. H. (2019), "Multicollinearity and misleading statistical results. Korean Journal of Anesthesiology", 72(6), 558-569. https://doi.org/10.4097/kja.19087.

Kissi, P. S., Nat, M., \& Armah, R. B. (2018), "The effects of learning-family conflict, perceived control over time and task-fit technology factors on urban-rural high school students' acceptance of video-based instruction in flipped learning approach", Educational Technology Research and Development, 66(6), 1547-1569.

Kweon, B. S., Ellis, C. D., Lee, J., \& Jacobs, K. (2017), "The link between school environments and student academic performance", Urban Forestry \& Urban Greening, 23, 35-43.

Lee, S. Y. \& Brand, J. L. (2005), "Effects of control over office workspace on perceptions of the work environment and work outcomes", J. Environ. Psychol., vol. 25, pp. 323-333, doi: 10.1016/j.jenvp.2005.08.001.

Leiva, L., Bohmer, M., Gehring, S., \& Kruger, A. (2012), "Back to the app: the costs of mobile application interruptions", In Proc. MobileHCI '12, ACM.

Mohammadi, H. (2015), "Investigating users' perspectives on e-learning: An integration of TAM and IS success model", Computer in Human Behavior, vol. 45, pp. 359-374, 2015

Moore, R., Vitale, D. \& Stawinoga, S. (2018), "The digital divide and educational equity: A look at students with very limited access to electronic devices at home", ACT Research \& Center for Equity in Learning. Available: https://files.eric.ed.gov/fulltext/ED593163.pdf.

Mushtaq, I., \& Khan, S. N. (2012), "Factors affecting students' academic performance", Global journal of management and business research, 12(9), 17-22.

Ndemo, B. (2020). "COVID-19 changes and the end of teaching as we know it". Available: https:/www.msn.com/en-za/news/other/covid-19-changes-and-the-end-of-teaching-as-we-know-it/arBB12GowC.

Oakman, J., Kinsman, N, Stuckey, R, Graham, M \& Weale, M. (2020), “A rapid review of mental and physical health effects of working at home: how do we optimize health", BMC Public Health, 1(20), pp. 1-13

Obeta, A. O. (2014). Home environmental factors affecting students' academic performance in Abia State, Nigeria. In Rural Environment. Education. Personality.(REEP). Proceedings of the International Scientific Conference (Latvia). Latvia University of Agriculture.

Okereke, M., Williams, A. E., Emmanuella, N. C., Ashinedu, N. U., \& Mairaj, M. W. (2020), "COVID-19: challenges affecting the uptake of e-learning in pharmacy education in Africa", The Pan African Medical Journal, 35(2).

Opoku, D., Pobee, F, \& Okyireh, R. O. (2020), "Determinants of E-Learning System Adoption among Ghanaian University Lecturers: An Application of Information System Success and Technology Acceptance Models", American Journal of Social Sciences and Humanities, 5(1), 151-168.

Pielot, M., Church, K., \& De Oliveira, R. (2014), “An in-situ study of mobile phone notifications" MobileHCI 2014 - Proceedings of the 16th ACM International Conference on Human-Computer Interaction with Mobile Devices and Services, 233-242. https://doi.org/10.1145/2628363.2628364

Rohman, M., Marji, D. A. S., Sugandi, R. M., \& Nurhadi, D. (2020), "Online learning in higher education during covid-19 pandemic: students' perceptions", Journal of Talent Development and Excellence, 12(2s), 36443651

Shahibi, M. S., \& Rusli, K. N. (2017). The influence of internet usage on student' $€^{\mathbf{T M}} \mathrm{s}$ academic performance. International Journal of Academic Research in Business and Social Sciences, 7(8), 873-887.

Sharma, A \& S. Vatta, S. (2013), "Role of learning management systems in education", International Journal of Advanced Research in Computer Science and Software Engineering”, no. 3(6), pp. 997-1002

Thongsri, N., Shen, L., \& Bao, Y. (2019)" Investigating academic major differences in perception of computer self-efficacy and intention toward e-learning adoption in China", Innovations in Education and Teaching International, 1-13. https://doi.org/10. 1080/14703297.2019.1585904.

Topor, D. R., Keane, S. P., Shelton, T. L., \& Calkins, S. D. (2010), "Parent involvement and student academic performance: A multiple mediational analysis", Journal of prevention \& intervention in the community, 38(3), 183-197.

Younas, M., Liu, C., Khalid, S., \& Bakar, A. (2021), “Effect of Home Environment On Students' academic Achievements At Higher Level”, Elementary Education Online, 19 ( 3): pp. 3931-3947 